ORIGINAL ARTICLE

\title{
Traumatic work related mortality among seafarers employed in British merchant shipping, 1976-2002
}

\author{
S E Roberts, P B Marlow
}

Occup Environ Med 2005;62:172-180. doi: 10.1136/oem.2003.012377

See end of article for authors' affiliations

......................

Correspondence to: Dr S Roberts, Unit of Health-Care

Epidemiology, Department of Public Health, University of Oxford, Old' Road, Oxford OX3 7LF, UK' stephen.roberts@uhce.ox. ac.uk

Accepted

29 September 2004
Aims: To establish the causes and circumstances of all traumatic work related deaths among seafarers who were employed in British merchant shipping from 1976 to 2002, and to assess whether seafaring is still a hazardous occupation as well as a high risk occupation for suicide.

Methods: A longitudinal study of occupational mortality, based on official mortality files, with a population of 1136427 seafarer-years at risk.

Results: Of 835 traumatic work related deaths, 564 were caused by accidents, 55 by suicide, 17 by homicide, and 14 by drug or alcohol poisoning. The circumstances in which the other 185 deaths occurred, including 178 seafarers who disappeared at sea or were found drowned, were undetermined. The mortality rate for 530 fatal accidents that occurred at the workplace from 1976 to 2002, 46.6 per 100000 seafarer-years, was 27.8 times higher than in the general workforce in Great Britain during the same time period. The fatal accident rate declined sharply since the 1970s, but the relative risk of a fatal accident was 16.0 in 1996-2002. There was no reduction in the suicide rate, which was comparable to that in most high risk occupations in Britain, from 1976 to 1995; but a decline since 1995.

Conclusions: Although there was a large decline in the fatal accident rate in British shipping, compared to the general workforce, seafaring has remained a hazardous occupation. Further prevention should focus on improvements in safety awareness among seafarers and shipping companies, reductions in hazardous working practices, and improvements in care for seafarers at risk of suicide.
T raditionally, merchant seafaring has been cited as the most hazardous of all occupations in Britain. Towards the end of the nineteenth century a Royal Commission, that had investigated the loss of life at sea in British merchant shipping, reported to the House of Lords that 26188 seafarers had died from accidents ( 1 in 73 per year) from 1875 to $1883 .{ }^{1}$ The fatal accident rate in seafaring at that time was also much higher than in other hazardous occupations, such as coal mining and railway work.

Although the fatal accident rate in British shipping had declined considerably, seafaring was again cited as the most dangerous occupation in Britain in the 1930s and the 1940 s. $^{23}$ An even higher fatal accident rate was subsequently reported for Swedish merchant shipping from 1945 to $1954{ }^{4}$ By the 1970s, however, trawler fishing was identified as the most hazardous occupation in Britain. ${ }^{5}$ Seafaring has also for long been identified as a high risk occupation for suicide. $^{46}$

The first aims of this study were to establish and analyse the causes and circumstances of all traumatic work related deaths among seafarers in British merchant shipping from 1976 to 2002. In earlier studies, it was reported briefly that seafaring was the second most dangerous occupation after commercial fishing in Great Britain in the period around the 1981 census, ${ }^{7}$ and all-cause mortality in British shipping was analysed during the 10 year period $1986-95 .^{8}$ In this study, an updated and more detailed analysis is provided for all fatal accidents and other traumatic work related deaths in British shipping between 1976 and 2002, with particular focus on long term time trends in death rates over the 27 year study period. The main aims were to establish whether seafaring has remained a particularly hazardous occupation, as well as a high risk occupation for suicide, and to discuss measures for the reduction of traumatic work related mortality.

\section{METHODS}

Work related deaths in British shipping are not usually registered with the local registrars of deaths, and are not included in routine national mortality statistics, but are registered separately by the Registrar General for Shipping and Seamen (RGSS). In this study, details of all deaths in British merchant shipping were identified from files at the RGSS and the principle maritime investigative authority, the Marine Accident Investigation Branch (MAIB). The causes and circumstances of deaths were established from postmortem examination reports, death certificates, reports of coroners' inquisitions, official marine inquiries, log books, and other documents. Details of each ship that the deceased had been employed on board at time of death were obtained from Lloyd's Register of Shipping vessel records, ${ }^{9}$ and vessel registry records at the RGSS.

\section{Inclusion criteria}

Included in this study were all traumatic work related deaths among seafarers who were "signed on" the articles of agreement and working on board British merchant ships of 100 gross registered tonnes and over between 1976 and 2002, provided that the deaths arose at work or within 30 days of any discharge ashore to hospital. The study excluded seafarers who were working on board ships with British "second register" fleets such as Gibraltar and the Isle of Man. Deaths among non-crew members such as passengers and dock workers were also excluded, as were deaths among crew in non-merchant ships such as fishing trawlers and yachts. The study period was from 1 January 1976 to 31 December 2002. A total of 835 deaths satisfied the inclusion criteria and were included.

\section{Certification of deaths}

Of the 835 deaths, 197 seafarers were lost at sea, a further 15 were buried at sea, and the source of death certification was 


\section{Main messages}

- Between 1976 and 2002, the fatal accident rate in British merchant shipping, 46.6 per 100000 seafareryears, was 27.8 times higher than in the general workforce of Great Britain.

- The fatal accident rate in British shipping fell from 65.5 per 100000 seafarer-years in 1976-80 to 15.0 in 1996-2002. However, since the relative risk with the general British workforce was 16.0 in 1996-2002, in relative terms, seafaring has remained a hazardous occupation.

- There was no decline in the suicide rate from 1976 to 1995, but there has been a decline since 1995 .

- The 225 fatal occupational accidents were largely caused by hazardous working practices and the recurrence of similar types of accidents.

- Almost half of the 163 fatal off-duty accidents were caused by seafarers falling into docks when returning to their ships from ashore, and were often caused by hazardous access conditions to the ships.

unavailable for the 38 seafarers who died when the passenger ferry Herald of Free Enterprise capsized. The results of a postmortem examination were available in at least 359 of the other 585 cases $(61 \%)$. Sixteen other diagnoses (3\%) were obtained from Scottish deaths registers, which usually record the underlying cause of death only and do not indicate whether a postmortem examination had been performed. Diagnoses were obtained from other medical sources in a further 148 cases $(25 \%)$, and through the British consulate, marine investigation, ship's captains, and shipping companies (unknown source of certification; 62, 11\%). Details of the deaths of the 197 seafarers who were lost at sea were obtained through the MAIB or other marine inquiries, coroners' inquisitions, procurator fiscals' fatal accident inquiries, and other inquiries.

\section{Population at risk}

The populations of seafarers annually employed in British merchant ships were obtained from official government publications; issued by the Department of Trade for 1976-81, the Department of Transport (1982-88), the MAIB (198995), and the Maritime and Coastguard Agency (19962002). ${ }^{10-13}$ In these source, seafarers were conventionally counted as if they had been working at sea for the whole of each year; they included seafarers who were ashore on leave, or sick, etc, but had not left seafaring, in order to allow for comparison with other industries. This yielded a total population of 1136427 seafarer-years at risk from 1976 to 2002. The number of seafarers employed fell from 101400 in 1976 to 23107 in 2002. Disaggregated population data, according to demographic factors such as the age, rank, and nationality of the seafarers, is not known by any authority.

During the study period, as most British ships were reregistered with "flags of convenience" such as Panama, Liberia, and Belize, the British merchant fleet contracted from 2919 ships of 100 gross tonnage or more (total of 32.7 million gross tonnage) in 1976 to 1051 ships (7.9 million gross tonnage) in 2002. ${ }^{14}{ }^{15}$ In 1976 the British merchant fleet was composed of 164 passenger ships (5.6\% of all ships), 544 tankers (18.6\%), 87 container ships (3.0\%), 273 bulk carriers $(9.4 \%), 1032$ general cargo ships $(35.4 \%), 161$ dredgers (5.5\%), 280 tugs $(9.6 \%), 149$ offshore vessels (5.1\%), and 229 other ships $(7.8 \%)$. In 2002, the corresponding figures were:

\section{Policy implications}

- Prevention of fatal accidents should be aimed at improvements in safety awareness among seafarers and shipping companies, reductions in hazardous working practices, improvements in the ship-shore access of small ships in port, and the use of risk assessment.

- Further prevention would benefit from international collaboration in seeking to identify the direct and indirect causes, and common causal patterns, of the different types of traumatic work related death.

- Since little is known about the mortality and morbidity of most of the world's 1.2 million seafarers, who are now employed with "flags of convenience" registries, future efforts should focus on conducting population based studies in these fleets.

passenger ships $(155,14.7 \%)$, tankers $(109,10.4 \%)$, container ships $(79,7.5 \%)$, bulk carriers $(20,1.9 \%)$, general cargo ships $(146,13.9 \%)$, dredgers $(61,5.8 \%)$, tugs $(184,17.5 \%)$, offshore vessels $(186,17.7 \%)$, and other ships $(111,10.6 \%)$.

\section{Statistical methods}

The statistical methods used include cause specific mortality rates, relative risks, and Spearman's rank correlation coefficients. Ninety five per cent confidence intervals for mortality rates were adjusted for event clustering; for example, when multiple lives were lost through a single ship foundering.

\section{RESULTS}

Of the 835 traumatic work related deaths, 564 were caused by accidents, 55 by suicide, 17 by homicide, and 14 through drug or alcohol poisoning (table 1). The circumstances in which the other 185 deaths occurred were inconclusive: 87 seafarers disappeared at sea, 91 others also went missing but were subsequently found drowned, and seven others died through injury or asphyxiation in undetermined circumstances.

All but five of the 835 deceased (99\%) were men; the five women were stewardesses on passenger ferries $(n=4)$ and an entertainer on a cruise ship. A total of 649 of the deceased (78\%) were British nationals, and 35 others (4\%) were also European, including Portuguese nationals $(n=10)$, Irish $(\mathrm{n}=8)$, and Spaniards $(\mathrm{n}=5)$. One hundred and nine $(13 \%)$ were Asian, mainly from India $(n=44)$, Hong Kong $(n=32)$, the Philippines $(n=11)$, and Bangladesh $(n=9)$, while the remainder were from West Africa and the Caribbean $(n=8$ each) and from various other countries $(n=26)$. The counties in which most of the 649 deceased British nationals were resident were Merseyside $(n=61)$, Kent $(n=58)$, Strathclyde $(\mathrm{n}=55)$, Tyne \& Wear $(\mathrm{n}=45)$, Yorkshire $(\mathrm{n}=43)$, and Hampshire $(\mathrm{n}=26)$.

The mean age at death was 38.5 years (SD 12.4; range 16$66)$. One hundred and thirty (16\%) were aged under 25 years, $50 \%$ were aged $25-44,34 \%$ were $45-64$, and three $(0.4 \%)$ were 65 or over. Of the 835 deaths, $388(46 \%)$ occurred in port, and 447 at sea. Of the deaths in port, 158 (41\%) occurred in the UK, 103 (27\%) in other European countries, 39 in Asia, 32 in North America, 25 in Africa, 18 in South America, and 13 in Australasia.

\section{Deaths from accidents}

The causes of death for the 564 accidents were drowning, presumed drowning, or hypothermia $(n=262)$, injury $(n=230)$, asphyxiation by fumes $(n=69)$, and other causes 
Table 1 Causes of all traumatic work related deaths among seafarers in British merchant shipping, 1976-2002

\begin{tabular}{|c|c|c|c|c|}
\hline \multirow{2}{*}{$\begin{array}{l}\text { Cause of death } \\
\text { Accidents }\end{array}$} & \multicolumn{2}{|c|}{ Number of deaths (\%) } & \multicolumn{2}{|c|}{$\begin{array}{l}\text { Mortality rate per } 100000 \\
\text { seafarer-years }(95 \% \mathrm{CI})\end{array}$} \\
\hline & & & & \\
\hline Maritime disasters & 176 & $(21.1)$ & 15.5 & $(4.8-26.2)$ \\
\hline Occupational accidents & 225 & $(26.9)$ & 19.8 & (16.8 to 22.8$)$ \\
\hline Off-duty accidents & 163 & (19.5) & 14.3 & (12.1 to 16.6$)$ \\
\hline Homicide & 17 & (2.0) & 1.5 & $(0.8$ to 2.2$)$ \\
\hline Suicide & 55 & (6.6) & 4.8 & (3.6 to 6.1$)$ \\
\hline Alcohol and drug intoxication & 14 & (1.7) & 1.2 & $(0.6$ to 1.9$)$ \\
\hline \multicolumn{5}{|l|}{ Unknown circumstances } \\
\hline Drowned & 91 & (10.9) & 8.0 & (6.4 to 9.7$)$ \\
\hline Missing at sea & 87 & (10.4) & 7.7 & (6.0 to 9.3 ) \\
\hline Other & 7 & $(0.8)$ & 0.6 & $(0.2$ to 1.1$)$ \\
\hline All accidents & 564 & $(67.5)$ & 49.6 & (38.4 to 60.8 ) \\
\hline All accidents at work ${ }^{*}$ & 530 & (63.5) & 46.6 & (35.5 to 57.8$)$ \\
\hline All traumatic work related deaths & 835 & $(100.0)$ & 73.5 & (61.9 to 85.1 ) \\
\hline
\end{tabular}

$(n=3)$. Accidents have been classified into three categories: firstly, maritime disasters which refer to an incident involving the ship such as a collision, foundering, or fire; secondly, occupational accidents occurring among individual seafarers through their work duties; and thirdly, off-duty accidents that occurred when seafarers were off-duty. A total of 176 deaths were caused by maritime disasters, 225 by occupational accidents, and 163 by off-duty accidents.

Of the 176 seafaring deaths from maritime disasters, 42 occurred when the largest British ship ever to founder, the bulk carrier Derbyshire, disappeared after hatch cover failure during a typhoon in the North Pacific. A further 38 seafarers, and 155 passengers, were killed when the passenger ferry Herald of Free Enterprise capsized in fine conditions after leaving the Belgian port of Zeebrugge with the bow doors left open. Thirty other seafarers were lost when seven smaller British ships foundered in gales or storms and rough seas around the British Isles. Nine further lives were lost when two ships were involved in collisions, and the remaining 57 deaths resulted from fires and explosions in 24 other ships.

The 225 fatal occupational accidents were largely caused by the recurrence of similar types of accidents, such as asphyxiation in holds, falls down or inside holds, and falls overboard (table 2). Most of the 225 deceased (189, 84\%) had

Table 2 Causes of all traumatic work related deaths according to the rank of the deceased in British merchant shipping, 1976-2002

\begin{tabular}{|c|c|c|c|c|c|c|c|c|}
\hline \multirow[b]{2}{*}{ Cause of death } & \multicolumn{8}{|c|}{ Rank of the deceased } \\
\hline & Captain & $\begin{array}{l}\text { Deck } \\
\text { officer* }\end{array}$ & Engineer* & $\begin{array}{l}\text { Deck } \\
\text { rating }\end{array}$ & $\begin{array}{l}\text { Engine room } \\
\text { rating }\end{array}$ & $\begin{array}{l}\text { Catering/ } \\
\text { steward }\end{array}$ & Other & (Total) \\
\hline \multicolumn{9}{|l|}{ Accidents } \\
\hline \multicolumn{9}{|l|}{ Maritime disasters } \\
\hline Foundered & 4 & 9 & 16 & 29 & 9 & 41 & 2 & $(110)$ \\
\hline Collision & 1 & 1 & 2 & 4 & 1 & & & (9) \\
\hline Fire or explosion & 1 & 2 & 17 & 10 & 15 & 9 & 3 & (57) \\
\hline \multicolumn{9}{|l|}{ Occupational accidents } \\
\hline Asphyxiated in holds & & 3 & & 16 & 1 & & & (20) \\
\hline Asphyxiated in the engine room & & 2 & 3 & & 5 & & & (10) \\
\hline Falls overboard & & 4 & 1 & 26 & 1 & 2 & 1 & (35) \\
\hline Falls down or inside in holds & & 5 & & 23 & & 2 & & (30) \\
\hline Other falls on board & & & 2 & 16 & 1 & & & (19) \\
\hline Struck by heavy seas on deck & & 4 & & 11 & 2 & & & (17) \\
\hline Struck by mooring and towing ropes & & 8 & 1 & 8 & 1 & & & (18) \\
\hline Struck by other moving objects & 1 & 8 & 3 & 29 & 10 & & 1 & (52) \\
\hline Other occupational accidents & & 1 & 7 & 7 & 9 & & & (24) \\
\hline \multicolumn{9}{|l|}{ Off-duty accidents } \\
\hline Falls into docks - returning to ship & 9 & 7 & 13 & 25 & 3 & 19 & 1 & (77) \\
\hline Falls overboard & & 3 & 1 & 1 & 1 & 1 & & (7) \\
\hline Falls on board & & & 4 & 3 & 5 & 3 & & (15) \\
\hline Traffic related accidents ashore & & 5 & 4 & 10 & 4 & 10 & 1 & (34) \\
\hline Swimming and diving accidents & & & 2 & 6 & 2 & 3 & 1 & (14) \\
\hline Other off-duty accidents & 1 & 3 & 3 & 5 & & 4 & & (16) \\
\hline Homicide & 1 & 2 & 1 & 7 & 2 & 4 & & (17) \\
\hline Suicide & 1 & & 6 & 19 & $\overline{7}$ & 22 & & (55) \\
\hline Drug and alcohol intoxication & 2 & 1 & 2 & 5 & & 4 & & (14) \\
\hline \multicolumn{9}{|l|}{ Unknown circumstances } \\
\hline Drowned & 3 & 7 & 19 & 38 & 3 & 20 & 1 & (91) \\
\hline Missing at sea & 2 & 6 & 10 & 28 & 12 & 28 & 1 & (87) \\
\hline Other & & 1 & & 1 & 1 & 4 & & (7) \\
\hline Total & 26 & 82 & 117 & 327 & 95 & 176 & 12 & (835) \\
\hline
\end{tabular}




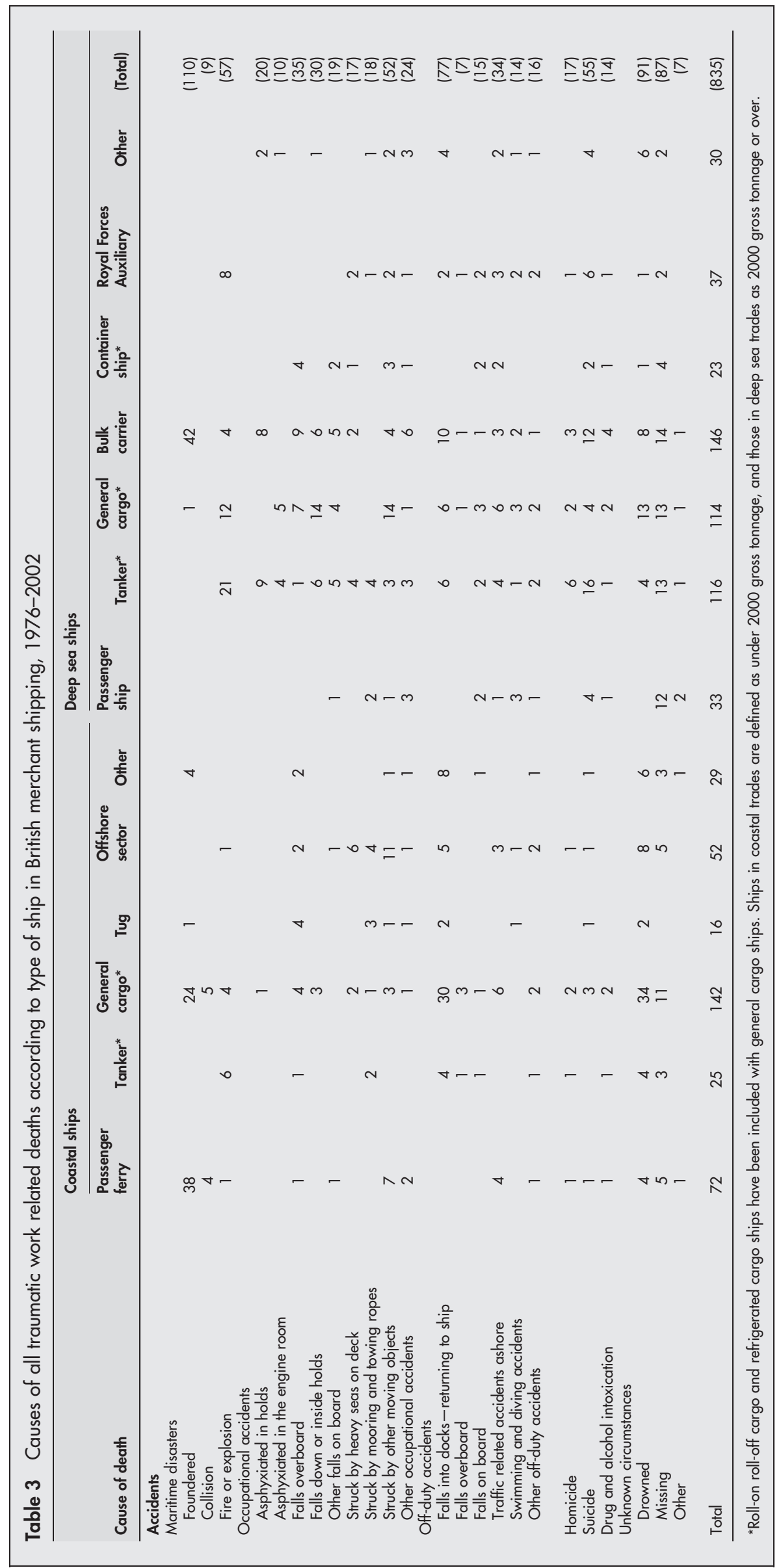


been working on deck areas at the time of the accident, and a further $29(13 \%)$ were in the engine room. The most frequent work duties at the time of accident were maintenance and repair work (47 fatalities), moving about the deck areas $(\mathrm{n}=32)$, loading and unloading cargoes $(\mathrm{n}=23)$, mooring operations $(n=18)$, painting $(n=16)$, cleaning $(n=12)$, opening hatch covers $(\mathrm{n}=11)$, and rigging or de-rigging gangways $(n=9)$. Most of the deceased $(171,76 \%)$ had been employed as deck ratings, deck officers, or deck cadets (table 2).

Most of the 225 occupational accidents (137, 61\%) occurred at sea. Only 37 of the deceased $(17 \%)$ were admitted to hospital before death, $14(6 \%)$ were dead on arrival, 125 $(56 \%)$ died on board their ships, 47 (21\%) drowned or were lost at sea, and the other two died on the quayside after falling overboard from their ships.

Of the 163 fatal off-duty accidents, 77 arose when seafarers fell into docks when returning to their ships from ashore. Sixty six of the 77 deceased $(86 \%)$ were reported to have been drinking alcohol ashore, 52 were returning with fellow crew, 21 were alone, and for four this was not documented. Thirty nine fell from gangways, 22 from the quayside, four fell when attempting to move between adjacently berthed ships, with 12 unseen or unreported locations of falls. Most of the 77 deceased $(49,64 \%)$ had been working in small coastal ships (less than 2000 gross tonnage; table 3). The other fatal offduty accidents were caused largely by traffic related accidents ashore ( 34 deaths) and by swimming or diving accidents (14 deaths). The traffic related accidents mainly refer to vehicle collisions and crashes (12 deaths), seafarers who were struck by vehicles when pedestrians ( 12 deaths), and cars that were driven into docks (6 deaths).

\section{Deaths from other traumatic work related causes}

Of 55 confirmed suicides, 30 jumped overboard, 20 were found hanged, three jumped from heights, and two died in other circumstances. They were variously linked to marital and other family problems, work related problems, delirium tremens, psychiatric or physical illness, social isolation, and other personal problems. Most of the suicides (35, 64\%) occurred at sea; almost all of the deceased had been employed as ratings $(26,47 \%)$ or as catering crew $(22,40 \%$; table 2), in large deep sea ships $(48,87 \%$; table 3$)$, and most $(36,65 \%)$ were British nationals.

Of 17 homicides, nine were killed by fellow seafarers, and eight by other assailants. Ten of the 17 died from stab wounds, five from other injuries, and two were asphyxiated. Seven other seafarers died from alcohol intoxication, and a further seven from drug poisoning.

Official inquiries were unable to establish the circumstances of 185 deaths. These include 87 seafarers who disappeared at sea, although there were reported indications that many had shown symptoms of suicide. A further 91 seafarers also went missing but were subsequently found drowned. All but five of the 91 had been off-duty; most of these $(55,64 \%)$ had been employed in small coastal trading ships, and most $(47,55 \%)$ were reported to have been drinking ashore. Although it is likely that most accidentally fell into docks when returning to their ships alone, the lack of evidence led coroners' inquisitions to record open verdicts. Finally, the circumstances surrounding seven other traumatic deaths were also uncertain.

\section{Trends in mortality rates}

Between 1976 and 2002, the mortality rate for fatal accidents occurring at the place at work for the general workforce of Great Britain was 1.7 per 100000 worker-years. ${ }^{16}$ In British shipping, 530 of the 564 fatal accidents occurred at the workplace, excluding the 34 traffic related accidents that occurred ashore. The corresponding fatal accident rate (46.6 per 100000 seafarer-years) was 27.8 times higher than in the general British workforce during the same period.

The annual fatal accident rate in shipping fluctuated considerably from 53 per 100000 in 1976 to 15 per 100000 in 2001-02 (Spearman's rank correlation $(S R)=-0.75$; $\mathrm{p}<0.001)$. Among the general workforce, there was also a large decline in the fatal accident rate from 2.9 per 100000 in 1976 to 0.8 per 100000 in 2002 ( $\mathrm{SR}=-0.96$; p < 0.001$)$.

Figure lA shows smoothed trends in fatal accident rates in British shipping, the general workforce, and the five main industrial sectors of Great Britain. The two peaks in the trend for shipping are largely due to the Derbyshire and Herald of Free Enterprise disasters in 1980 and 1987; the peak for the energy and water supply industry refers to the Piper Alpha oil rig disaster with 167 deaths in 1988. Seafaring has remained more hazardous than each of the industrial sectors, although the differential with agriculture, forestry, and fishing has narrowed in recent years. The comparative rates of change in fatal accident rates across the different industries are better scrutinised using logged rates (fig $1 \mathrm{~B}$ ). These show similar reductions in the fatal accident rate in shipping and the general workforce.

The quinnquennial fatal accident rate in seafaring fluctuated non-significantly from 65.5 per 100000 seafarer-years in 1976-80 to 55.4 in 1986-90, fell to 16.0 in 1991-95, and levelled off to 15.0 in 1996-2002 (table 4). The corresponding relative risk, with the general British workforce, fell from 25.5 in 1976-80 to 12.8 in 1991-95, but increased to 16.0 in 1996-02. If unexplained drownings, most likely caused by accidental falls, were also included as accidents, the relative risk during 1996-2002 would be 18.1.

The suicide rate in British shipping during the four quinnquennium 1976-80 to 1991-95 was, respectively, 5.4, $5.9,4.4$, and 5.1 per 100000 seafarer-years: it then declined to 1.3 in 1996-2002. There was no significant trend in the annual suicide rate from 1976 to 1995 ( $S R=-0.08$; $\mathrm{p}=0.73$ ), but a decline since 1995. There were significant reductions in the annual homicide rate $(S R=-0.58$; $\mathrm{p}=0.002)$ and in the rate for all traumatic work related deaths $(\mathrm{SR}=-0.84 ; \mathrm{p}<0.001)$.

Table 5 shows the number of deaths, and corresponding mortality rates, for the different types of traumatic work related death in three time periods: 1976-79 when the British fleet was still one of the largest in the world; 1980-89 when most deep sea trading ships were "flagged out"; and 19902002 when the British fleet comprised largely of small coastal ships. The main types of death that have persisted through to the 1990s include seafarers being struck by mooring and towing ropes, and by other moving objects, falls overboard, falls on board, traffic accidents, falls into docks and other unexplained drowning when returning to ships from ashore.

\section{DISCUSSION}

This study, an investigation of 835 traumatic work related deaths in a total population of over one million seafarer-years at risk, is the largest in-depth study of work related mortality in a defined population of merchant seafarers for over 40 years. The relative risk of a fatal accident at work in seafaring, compared with the general British workforce, declined from 26 in 1976-80 to 13 in 1991-95, but has increased to 16 in 1996-2002. This is slightly higher than a corresponding relative risk of 11 for British shipping in 1959-63, compared with the general British workforce of employees in 1961. ${ }^{17} 18$ In relative terms, therefore, seafaring has remained a hazardous occupation.

In recent years, fatal accident rates in various commercial fishing fleets ${ }^{19-23}$ have normally been substantially higher than in merchant shipping. ${ }^{24-26}$ Nonetheless, and with the 

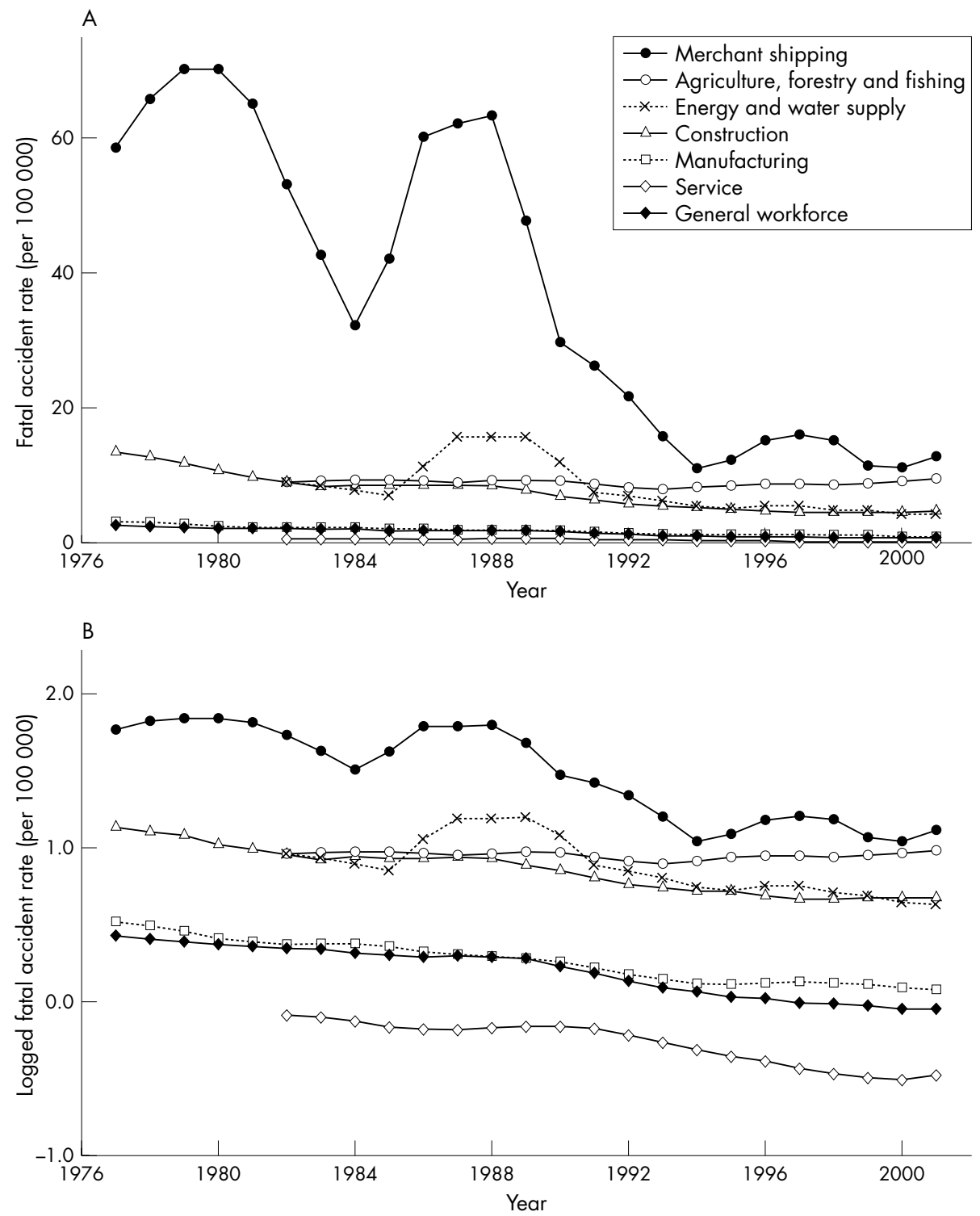

Figure 1 Trends in fatal accident rates (for accidents at work) in British merchant shipping, the general workforce, and the five main industrial sectors of Great Britain, 1976-2002; shown as weighted five year moving averages. (A) Fatal accident rate (per 100000 worker-years). (B) Logged fatal accident rate (per 100000 worker-years). The fatal accident rate for UK merchant shipping is based on original study data collected from files at the RGSS and the MAIB. Figures for the general workforce and for all other industries are based on HSE statistics and cover Great Britain only. All figures refer to 1976-2002, except those for energy and water supply, agriculture, forestry, and fishing, and the service industries that cover the period 19812002. The figures for energy and water supply include employees only and exclude the small number of self-employed. The figures for agriculture, forestry, and fishing exclude sea fishing. The figures for the general workforce in Great Britain exclude sea fishing, merchant seafaring, and civil aviation which are not covered under HSE legislation. The UK covers England, Wales, Scotland, and Northern Ireland; Great Britain comprises England, Wales, and Scotland.

Table 4 Trends in the fatal accident rate (for accidents at work) in British merchant shipping, 1976-2002

\begin{tabular}{llllll}
\hline Time period & $\begin{array}{l}\text { Deaths from } \\
\text { accidents at } \\
\text { work }\end{array}$ & Population at risk & Fatal accident rate (95\% Cl) & $\begin{array}{l}\text { Relative risk } \\
\text { seafarers: general } \\
\text { British workforce }\end{array}$ \\
\hline $1976-1980$ & $289^{*}$ & 441200 & 65.5 & $(44.2$ to 86.9$)$ & 25.5 \\
$1981-1985$ & 124 & 288000 & 43.1 & $(30.5$ to 55.6$)$ & 20.1 \\
$1986-1990$ & $75 \dagger$ & 135500 & 55.4 & $(26.1$ to 84.7$)$ & 28.9 \\
$1991-1995$ & 19 & 118419 & 16.0 & $(8.1$ to 24.0$)$ & 12.8 \\
$1996-2002$ & 23 & 153308 & 15.0 & $(8.9$ to 21.1$)$ & 16.0 \\
& & & & & \\
$1976-2002$ & 530 & 1136427 & 46.6 & $(35.5$ to 57.8) & 27.8 \\
\hline
\end{tabular}

*Includes the 42 seafaring deaths that occurred when the bulk carrier Derbyshire foundered in the North Pacific. tIncludes the 38 seafaring deaths that occurred when the passenger ferry Herald of Free Enterprise capsized off Belgium. 
Table 5 Trends in the number of deaths, and corresponding mortality rates, for different causes of traumatic work related death in British merchant shipping, 1976-79, 1980-89, and 1990-2002

\begin{tabular}{|c|c|c|c|c|c|c|c|c|}
\hline \multirow[b]{2}{*}{ Cause of death } & \multicolumn{2}{|c|}{$1976-79$} & \multicolumn{2}{|c|}{$1980-89$} & \multicolumn{2}{|c|}{ 1990-2002 } & \multicolumn{2}{|c|}{ 1976-2002 } \\
\hline & $\begin{array}{l}\text { No. of } \\
\text { deaths }\end{array}$ & $\begin{array}{l}\text { (mortality rate } \\
\text { per } 100000 \\
\text { seafarer- } \\
\text { years) }\end{array}$ & $\begin{array}{l}\text { No. of } \\
\text { deaths }\end{array}$ & $\begin{array}{l}\text { (mortality rate } \\
\text { per } 100000 \\
\text { seafarer- } \\
\text { years) }\end{array}$ & $\begin{array}{l}\text { No. of } \\
\text { deaths }\end{array}$ & $\begin{array}{l}\text { (mortality rate } \\
\text { per } 100000 \\
\text { seafarer- } \\
\text { years) }\end{array}$ & $\begin{array}{l}\text { No. of } \\
\text { deaths }\end{array}$ & $\begin{array}{l}\text { (mortality rate } \\
\text { per } 100000 \\
\text { seafarer- } \\
\text { years) }\end{array}$ \\
\hline \multicolumn{9}{|l|}{ Accidents } \\
\hline \multicolumn{9}{|l|}{ Maritime disasters } \\
\hline Foundered & 21 & $(5.8)$ & 89 & (18.6) & & & 110 & (9.7) \\
\hline Fire or explosion & 18 & (5.0) & 35 & (7.3) & 4 & (1.4) & 57 & (5.0) \\
\hline Other & 5 & (1.4) & 4 & $(0.8)$ & & & 9 & $(0.8)$ \\
\hline \multicolumn{9}{|l|}{ Occupational accidents } \\
\hline Asphyxiated in holds & 18 & $(5.0)$ & 2 & (0.4) & & & 20 & (1.8) \\
\hline Asphyxiated in the engine room & 4 & (1.1) & 6 & (1.3) & & & 10 & (0.9) \\
\hline Falls overboard & 13 & (3.6) & 17 & (3.6) & 5 & (1.7) & 35 & (3.1) \\
\hline Falls down or inside holds & 20 & (5.5) & 8 & (1.7) & 2 & (0.7) & 30 & (2.6) \\
\hline Other falls on board & 14 & (3.9) & 1 & (0.2) & 4 & (1.4) & 19 & (1.7) \\
\hline Struck by heavy seas on deck & 7 & (1.9) & 9 & (1.9) & 1 & (0.3) & 17 & (1.5) \\
\hline Struck by mooring and towing ropes & 8 & (2.2) & 6 & (1.3) & 4 & (1.4) & 18 & (1.6) \\
\hline Struck by other moving objects & 20 & (5.5) & 21 & (4.4) & 11 & (3.7) & 52 & (4.6) \\
\hline Other occupational accidents & 10 & (2.8) & 9 & (1.9) & 5 & (1.7) & 24 & (2.1) \\
\hline \multicolumn{9}{|l|}{ Off-duty accidents } \\
\hline Falls into docks - returning to ship & 39 & $(10.7)$ & 32 & (6.7) & 6 & (2.0) & 77 & (6.8) \\
\hline Falls overboard & 2 & $(0.6)$ & 3 & (0.6) & 2 & (0.7) & 7 & (0.6) \\
\hline Falls on board & 8 & (2.2) & 5 & (1.0) & 2 & (0.7) & 15 & (1.3) \\
\hline Traffic accidents ashore & 12 & (3.3) & 16 & (3.3) & 6 & (2.0) & 34 & (3.0) \\
\hline Swimming and diving accidents & 4 & (1.1) & 8 & (1.7) & 2 & (0.7) & 14 & (1.2) \\
\hline Other off-duty accidents & 8 & $(2.2)$ & 8 & (1.7) & & & 16 & (1.4) \\
\hline Homicide & 10 & (2.8) & 6 & (1.3) & 1 & (0.3) & 17 & (1.5) \\
\hline Suicide & 20 & (5.5) & 26 & (5.4) & 9 & (3.0) & 55 & (4.8) \\
\hline Drug and alcohol intoxication & 4 & (1.1) & 8 & (1.7) & 2 & (0.7) & 14 & (1.2) \\
\hline \multicolumn{9}{|l|}{ Unknown circumstances } \\
\hline Drowned & 53 & (14.6) & 28 & (5.9) & 10 & (3.4) & 91 & (8.0) \\
\hline Missing & 45 & (12.4) & 35 & (7.3) & 7 & (2.4) & 87 & $(7.7)$ \\
\hline Other & 4 & (1.1) & 2 & $(0.4)$ & 1 & (0.3) & 7 & (0.6) \\
\hline Total & 367 & (101.2) & 384 & $(80.4)$ & 84 & $(28.4)$ & 835 & (73.5) \\
\hline
\end{tabular}

occasional exception, ${ }^{27}$ those in seafaring have usually been, at least in advanced western countries, higher than those published for other occupations and industries. Seafaring is therefore often the second most hazardous occupation after commercial fishing in advanced western countries.

The overall fatal accident rate in British shipping from 1976 to 2002, 49.6 per 100000 seafarer-years, was broadly comparable with those in other European fleets during the 1980s and the 1990s. ${ }^{24-26}$ It was, however, much lower than in earlier studies; 1364 per 100000 in British shipping from 1875 to $1883,{ }^{1} 156$ per 100000 in British shipping from 1935 to $1937,{ }^{2}$ and 370 in Swedish shipping from 1945 to 1954. ${ }^{4}$ The decline in mortality over time is largely due to improvements in shipping design and technology, reductions in shipping casualties, and improvements in health and safety.

During the 27 year study period, the continuing decline in the fatal accident rate is most likely also linked to the same factors. Nonetheless, it is also because of two further reasons. Firstly, most British cargo carrying ships were "flaggedout" to flags of convenience registries in the 1980s: fatal occupational accident rates are often higher in cargo-carrying ships, ${ }^{28}$ and shipping casualty rates tend to be higher for flags of convenience fleets. ${ }^{29}{ }^{30}$ Secondly, there has been no major maritime disaster, with more than two lives lost, in British shipping since 1988: major disasters such as the Derbyshire and the Herald of Free Enterprise can substantially inflate fatal accident rates in most seafaring populations.

Most of the 225 fatal occupational accidents occurred among deck ratings and deck officers, and were characterised by the recurrence of similar types of accidents, often during particular work duties. For example, falls on board or overboard ships caused almost $40 \%$ of these accidents, and have persisted through to the 1990s. They largely involved falls into or inside holds, off ladders or down stairways, falls from heights when painting or cleaning, and falls overboard when rigging or de-rigging gangways. A more widespread use of safety belts or harnesses among seamen engaged in duties that placed them at risk from potentially fatal falls would have prevented many deaths. The provision and use of life jackets or buoyancy vests would have improved survival chances for those who fell or were washed overboard.

Other types of fatal accidents that have persisted through the 1990s include seafarers being struck by mooring and towing ropes and by other moving objects, traffic accidents, and falls into docks when returning to ships from ashore. These falls and other unexplained drownings in docks, which were also most likely caused by accident falls, accounted for about 130 deaths. Although most of the deceased had been drinking ashore, access to small ships, via makeshift gangways and even ladders, was often hazardous. As previously recommended, ${ }^{425}$ prevention should be aimed at more elaborate gangways, the use of effective safety nets, improved lighting in the dock area, and efforts to ensure that inebriated colleagues are never left ashore to return to the ship alone. In general, prevention of fatal accidents should be directed towards improved safety awareness among seafarers and shipping companies, reductions in hazardous working practices, the use of risk assessment, and improvements in the ship-shore access to small vessels in port.

Although the number of suicides fell after 1995, the work related suicide rate was 4.8 per 100000 seafarer-years from 
1976 to 2002 . However, seafaring is a unique occupation with an abnormally high number of "open verdict" and other unexplained deaths: 178 in this study were due to disappearances at sea or seafarers who were found drowned. From examining official inquiry files, suicide was the most plausible cause of death in about half of these 178 cases. This indicates a work related suicide rate of about 14 per 100000 , which is much higher than a corresponding rate of 0.23 per 100000 for the general US workforce. ${ }^{31}$ Although the seafaring suicide rate may be inflated by suicides among foreign seafarers, it is higher or comparable to (overall) suicide rates in all but the few highest risk occupations in Britain. These are veterinarians and pharmacists (with overall "suicide and open verdict" rates of about 80 and 45 per 100000 worker-years respectively), ${ }^{32}$ and dentists, doctors, and farmers (with overall rates of $18-35$ per 100000 )..$^{32} 33$ However, as many seafarers spend about half their time "signed off" their ships, and on shore leave, the overall suicide rate among seafarers would most likely be substantially increased above 14 per 100000 .

As almost $90 \%$ of suicides occurred among ratings and catering crew, as previously found, ${ }^{6} 3435$ suicide risks are strongly associated with the rank of the seafarer. Since almost $90 \%$ of the suicides occurred among seafarers in deep sea trading ships, the decline of the British deep sea sectors may, at least to some extent, explain the recent reduction in the suicide rate. Prominent risk factors in the relation between occupation and suicide include access to a means of suicide, social isolation, job insecurity, work related stress, and a constantly changing working environment. ${ }^{36}{ }^{37}$ Seafarers in deep sea trading ships are often at sea continuously for weeks or months and can be exposed to isolated social and working conditions, made worse by recent reductions in ship crewing numbers, as well as long term separation from family. These together with other reported factors such as frequent changing of ships and job insecurity would explain some of the high risk of suicide in seafaring. Perhaps most importantly, since the method used was drowning in 55\% of all confirmed suicides, and in $87 \%$ of all confirmed or possible suicides, easy access to this particular means would also explain the high suicide rate. Prevention should include, as recommended previously, ${ }^{6}$ improved training for ships' officers in the identification and treatment of psychiatric illness, and the publication of guidelines on caring for seafarers at risk from suicide.

Due to a lack of disaggregated population information, it was not possible to investigate for differences in mortality rates according to demographic factors such as ethnicity and rank. However, using official mortality figures for the earlier period 1960-72,1738 39 the fatal accident rate was slightly lower among Asian seamen who were signed on "Asiatic agreements" in British shipping (70 per 100000 seafareryears) than among the (mainly British) rest of the population at risk (77 per 100000 ), but the suicide rate was substantially higher among the Asian seamen (23 v 14 per 100000$)$. The lower fatal accident rate among the Asian seamen was largely because they were often recruited as catering crew or stewards rather than as deck ratings or officers, and therefore had a lower risk of a fatal occupational accident at work. Also, since World Health Organisation figures show that suicide rates among men in Britain have been typically higher than, or similar to, those among men in India, this indicates that the increased suicide mortality among Asian seamen was specific to the occupational environment.

In this study, the declining fatal accident rate in British shipping has coincided with the re-registering of most higher risk cargo carrying ships with flags of convenience such as Panama, Liberia, and Belize, that now employ most of the world's 1.2 million seafarers. Although shipping casualty rates are highest in many of these registries, ${ }^{29}{ }^{30}$ a lack of mortality, morbidity, and population information has, so far, hindered attempts to conduct population based studies for seafarers employed in these fleets. Future research should focus on investigating the mortality and health of seafarers working for flags of convenience registries.

The fatal accident rate in British shipping declined heavily from 1976 and 2002, and has coincided with the depletion of the higher risk cargo carrying sectors as well as the absence of a recent shipping casualty with heavy loss of life. During the study period there was also a sharp reduction in the fatal accident rate in the general workforce of Great Britain. Since the risk of a fatal accident rate in British shipping is still 16 times greater than for the average worker, in relative terms, seafaring has remained a hazardous occupation.

\section{ACKNOWLEDGEMENTS}

This study was supported by funding from the International Transport Federation Seafarers' Trust. The authors are grateful to the Registrar General for Shipping and Seamen and the Marine Accident Investigation Branch for providing access to their mortality files, to John Crilley of Lloyd's Register for advice and help with shipping classifications and legislation, and to Ruth M Ripley for help with adjustment of confidence intervals for multiple fatalities arising through the same accident.

\section{Authors' affiliations}

S E Roberts, Unit of Health-Care Epidemiology, Department of Public Health, University of Oxford, Oxford, UK

P B Marlow, Cardiff Business School, Cardiff University, Cardiff, UK

Competing interests: none declared

\section{REFERENCES}

1 Royal Commission on Loss of Life at Sea. First report of the Royal Commission on Loss of Life at Sea with minutes of evidence. London: Eyre and Spottiswoode, 1885.

2 Home WE. Mortality of British merchant seamen. Lancet 1934;225:1081-3.

3 Carr GJ. Health problems in the merchant navy. Br J Ind Med 1945;2:65-73.

4 Otterland A. A sociomedical study of the mortality in merchant seafarers. Gotebörg: Scandinavian University Books, 1960.

5 Schilling RSF. Hazards of deep-sea fishing. Br J Ind Med 1971;28:27-35.

6 Wickstrom G, Leivonniemi A. Suicides among male Finnish seafarers. Acta Psychiatr Scand 1985;71:575-80.

7 Roberts SE. Hazardous occupations in Great Britain. Lancet 2002;360:543-4.

8 Roberts SE, Hansen HL. An analysis of the causes of mortality among seafarers in the British merchant fleet (1986-1995) and recommendations for their reduction. Occup Med 2002;52:195-202.

9 Lloyd's Register of Shipping. Register of ships, 1976-2002 [annual returns]. London: Lloyd's Register of Shipping, 1977-2003.

10 Department of Trade. Casualties to vessels and accidents to men. Vessels registered in the United Kingdom. Returns for 1976-1981. London: HMSO, 1977-82).

11 Department of Transport. Casualties to vessels and accidents to men. Vessels registered in the United Kingdom, returns for 1982-1988. London: HMSO, 1983-89).

12 Marine Accident Investigation Branch. Annual reports, 1989-1995. London: HMSO, 1990-96).

13 Maritime and Coastguard Agency. Annual report and accounts, 2002-03. London: London Stationary Office, 2003.

14 Lloyd's Register of Shipping. Statistical tables, 1976-1992 [annual returns]. London: Lloyd's Register of Shipping, 1977-93.

15 Lloyd's Register of Shipping. World fleet statistics, 1993-2002 [annual returns]. London: Lloyd's Register of Shipping, 1994-2003.

16 Health and Safety Executive. Health and safety statistics [annual reports]. London: HMSO, 1977-2003.

17 Ministry of Transport. Shipping casualties and deaths: vessels registered in the United Kingdom, returns for 1959-63. London: HMSO, 1960-64.

18 Cooper J. Occupational injuries at work. In: Drever F, ed. Occupational health: decennial supplement. London: HMSO, 1995:185-94.

19 Hasselback P, Neutel Cl. Risk for commercial fishing deaths in Canadian Atlantic provinces. Br J Ind Med 1990;47:498-501.

20 Schnitzer PG, Landen DD, Russell JC. Occupational injury deaths in Alaska's fishing industry, 1980 through 1988. Am J Public Health 1993:83:685-8.

21 Driscoll TR, Ansari G, Harrison JE, et al. Traumatic work related fatalities in commercial fishermen in Australia. Occup Environ Med 1994;51:612-16.

22 Jensen OC. Analyse af anmeldte fiskeriulykker til Søfartsstyrelsen, 1988-1992 [Analysis of the reported fishing injuries to the Danish Maritime Authority, 1988-1992]. Esbjerg: Institute of Maritime Medicine, South Jutland University Centre, 1994. 
23 Roberts SE. Occupational mortality in British commercial fishing, 1976-95. Occup Environ Med 2004;61:16-23.

24 Larsson TJ, Lindquist C. Traumatic fatalities among Swedish seafarers, 198488. Safety Sci 1992;15:173-82

25 Hansen HL. Surveillance of deaths on board Danish merchant ships, 1986-93: implications for prevention. Occup Environ Med 1996;53:269-75

26 Jaremin B, Kotulak E, Starnawska M, et al. Causes and circumstances of deaths of Polish seafarers during sea voyages. J Travel Med 1996;3:91-5.

27 Marshall SW, Kawachi I, Cryer PC, et al. The epidemiology of forestry workrelated injuries in New Zealand, 1975-88: fatalities and hospitalisations. N Z Med J 1994:107:434-7.

28 Hansen HL, Nielsen D, Frydenberg M. Occupational accidents aboard merchant ships. Occup Environ Med 2002;59:85-91.

29 Lloyd's Register of Shipping. World casualty statistics, 1993-2002 [annual returns]. London: Lloyd's Register of Shipping, 1994-2003.

30 Lloyd's Register of Shipping. World fleet statistics, 1993-2002 [annual returns]. London: Lloyd's Register of Shipping, 1994-2003.

31 Conroy C. Suicide in the workplace: incidence, victim characteristics, and external cause of death. J Occup Med 1989;31:847-51.
32 Office of Population Censuses and Surveys. Occupational mortality: decennial supplement, 1979-80, 1982-83, Great Britain [microfiche tables]. Series DS no.6. London: HMSO, 1986.

33 Hawton K, Clements A, Sakarovitch C, et al. Suicide in doctors: a study of risk according to gender, seniority and speciality in medical practitioners in England and Wales, 1979-1995. J Epidemiol Community Health 2001;55:296-300.

34 Brandt LP, Kirk NU, Jensen OC, et al. Mortality among Danish merchant seamen from 1970 to 1985. Am J Ind Med 1994;25:867-76.

35 Hansen HL, Pedersen G. Influence of occupational accidents and deaths related to lifestyle on mortality among merchant seafarers. Int J Epidemiol 1996;25:1237-43.

36 Shepherd DM, Barraclough BM. Work and suicide: an empirical investigation. Br J Psychiatry 1980;136:469-78.

37 Boxer PA, Burnett C, Swanson N. Suicide and occupation: a review of the literature. J Occup Environ Med 1995;37:442-52.

38 Board of Trade. Shipping casualties and deaths: vessels registered in the United Kingdom, returns for 1964-68. London: HMSO, 1965-69.

39 Department of Trade and Industry. Shipping casualties and deaths: vessels registered in the United Kingdom, returns for 1969-72. London: HMSO, 1970-73.

Committee on Publication Ethics Seminar 2005

Friday 11 March 2005, 9.30 am - 5 pm, BMA House, London

This year's seminar will focus on COPE's new Code of Conduct for Editors and interactive workshops on common ethical and editorial dilemmas. The seminar is for editors, authors, and all those interested in increasing the standard of publication ethics.

The Code aims to set a new basic standard for the ethical conduct of editors and sets out guidelines for quality and correcting the record, standing by decisions made, ethics committee approval, consent for publication confidentiality of submitted material, guidance to authors, pursuing misconduct, relationship to publishers, owners, and advertisers, and conflict of interest. The code also creates a mechanism to refer a complaint to COPE if an editor has breached the code.

The seminar will include:

- The new Code of Conduct for Editors

- Dr lona Heath, Chair BMJ Ethics Committee-research, audit, and ethics committee approval

- COPE's new website-full text and keyword searching for COPE's advice on specific issues, for example research misconduct, conflict of interest, and deception

- Interactive workshops-common ethical and editorial dilemmas for editors

- Opportunities to network with other editors and share your experiences and challenges

The seminar is free for COPE members and $£ 30.00$ for non-members. Numbers are limited and early booking is advisable. For registrations or more information please contact Sam Knottenbelt at cope@bmigroup.com or call 0207383 6602. For more information on COPE see www.publicationethics.org.uk/ 